(c) American Dairy Science Association, 2006.

\title{
Genetic Parameters and Evaluation of Rear Legs (Rear View) for Brown Swiss and Guernseys
}

\author{
G. R. Wiggans, ${ }^{* 1}$ L. L. M. Thornton, ${ }^{*}$ R. R. Neitzel, $†$ and N. Genglerł \\ *Animal Improvement Programs Laboratory, Agricultural Research Service, USDA, Beltsville, MD 20705-2350 \\ †Brown Swiss Cattle Breeders' Association of the USA, Beloit, WI 53511-5456 \\ $\ddagger$ National Fund for Scientific Research, B-1000 Brussels, Belgium, and Animal Science Unit, Gembloux Agricultural University, \\ B-5030 Gembloux, Belgium
}

\begin{abstract}
Genetic parameters were estimated for rear legs (rear view; RLRV) and 15 current linear type traits of Brown Swiss and Guernsey dairy cattle. The Brown Swiss Cattle Breeders' Association of the USA and the American Guernsey Association began scoring RLRV in 2004. For Brown Swiss, 8,502 records were available for 7,676 cows in 417 herds; Guernsey data included 5,437 records for 4,749 cows in 229 herds. Nine unknown-parent groups were defined for each breed, each with 2 birth years. The model included fixed effects for the interaction of herd, appraisal date, and parity; appraisal age within parity; and lactation stage within parity and random effects for animal, permanent environment, and residual error. The multitrait analysis for RLRV and the 15 linear type traits used canonical transformation, multiple diagonalization, and a decelerated expectation-maximization REML algorithm. For Brown Swiss, heritability was 0.102 for RLRV and ranged from 0.099 for rear legs (side view) to 0.453 for stature. For Guernseys, heritability ranged from 0.078 for RLRV to 0.428 for stature. For Brown Swiss, the highest genetic correlation with RLRV was 0.71 for rear udder width; the most negative correlation was -0.19 with rump angle. For Guernseys, the highest genetic correlations with RLRV were 0.43 for rear udder width and 0.42 for body depth; the most negative correlation was -0.46 with rear legs (side view). With heritability near 0.10 , RLRV should be useful in selection for improved locomotion. Release of genetic evaluations for RLRV began in May 2006 for Brown Swiss and Guernseys.
\end{abstract}

Key words: rear legs, type trait, genetic evaluation

\section{INTRODUCTION}

Mobility is a growing concern in today's intensive dairy environments, both for confinement operations,

Received May 3, 2006.

Accepted August 2, 2006.

${ }^{1}$ Corresponding author: wiggans@aipl.arsusda.gov where cows are on slippery concrete for most of the time, and for grazing situations, where cows are required to walk long distances. Lameness is the third most likely cause of involuntary culling after fertility and mastitis (National Animal Health Monitoring System, 2002). Boettcher et al. (1998) suggested that selection for rear legs (rear view; RLRV) may help to reduce locomotion problems because of its relatively high genetic correlation with clinical lameness.

The Brown Swiss Cattle Breeders' Association of the USA (BSA; Beloit, WI) and the American Guernsey Association (AGA; Reynoldsburg, OH) added the trait RLRV to their linear appraisal programs in 2004 to address mobility problems (Neitzel, 2004; S. Johnson, AGA, Reynoldsburg, OH, personal communication). The BSA began scoring RLRV to more easily detect bulls that sire daughters with mobility problems caused by the rear leg set and with short herd life as well as daughters with infertility caused by locomotion problems. The AGA identified RLRV as potentially more useful than rear legs (side view) in detecting mobility problems that influence productive life. The Holstein Association USA (Brattleboro, VT) has included RLRV in its feet-and-legs composite since January 1996 (Holstein Association USA, 1996).

The BSA scores RLRV from 1 to 9 . A score of 1 indicates a rear leg that is severely hocked in and toed out; a score of 9 indicates legs that are directly perpendicular to the ground and may be toed in. The AGA scores RLRV from 1 to 50. The difference in scoring scale is also present for all linear traits that are appraised by these 2 breed associations. The Brown Swiss 9-point scale was implemented because of its slightly greater accuracy than the 50-point scale (R. R. Neitzel, unpublished data) and to accommodate rapid data entry into handheld computers (Neitzel, 2003). For genetic evaluation, Brown Swiss scores on the 9-point scale are multiplied by 5 to combine them with historical data on the 50-point scale.

Although feet and leg traits tend to have little relationship to actual profit, a positive linear relationship has been found between those traits and survival and 
functional herd life (Norman et al., 1996; Pérez-Cabal and Alenda, 2002). In general, a score for RLRV that is slightly straighter than midrange is preferred (Fatehi et al., 2003) because of a positive relationship between RLRV and productive life (Rogers, 1996; Tsuruta et al., 2005), but extremes are not desirable (Caraviello et al., 2004; Sewalem et al., 2004). Although no direct link appears to exist between RLRV and fertility or milk production, a low-scoring animal may have greater fertility problems and lower milk production because of reduced mobility (Shapiro and Swanson, 1991; Boettcher et al. 1998). Several studies have found low heritability estimates for RLRV, with a range of 0.09 to 0.12 (Fuerst-Waltl et al., 1998; DeGroot et al., 2002; Reinhardt et al., 2005). The Holstein Association USA uses a heritability of 0.11 in its evaluation of RLRV and places 37\% emphasis on RLRV in the feet-and-legs composite (Holstein Association USA, 1996).

A majority of participants in the International Bull Evaluation Service (Interbull, Uppsala, Sweden) collect and use RLRV in their national evaluations for the Holstein breed; few use RLRV to evaluate the conformation of other breeds (International Bull Evaluation Service, 2006a). Only New Zealand and the Czech Republic do not include an RLRV component for type evaluation of Holsteins (International Bull Evaluation Service, 2006b). Jerseys and Ayrshires are the colored breeds that are most frequently evaluated for RLRV internationally. Although Interbull does not currently collect Brown Swiss RLRV data for international genetic evaluation, Canada, Germany-Austria, France, The Netherlands, Switzerland, and the United States provide an overall feet-and-legs composite. For Guernseys, Australia, Canada, the United Kingdom, and the United States contribute a feet-and-legs composite, and Australia and Canada also provide RLRV as an individual trait (International Bull Evaluation Service, 2006b).

A multitrait animal model (Gengler et al., 1997a, 1997b, 1999) has been used to calculate type evaluations for Brown Swiss and Guernseys since February 1998. The purpose of this study was to estimate genetic parameters for RLRV and to develop a genetic evaluation system for this trait.

\section{MATERIALS AND METHODS}

\section{Data}

Brown Swiss data were 8,502 records from 2004 through March 2006 for 7,676 cows in 417 herds. Scores were assigned by 16 appraisers; 2 appraisers contributed $43 \%$ of the appraisals. Pedigree data $(23,353$ records) included ancestors born during 1985 and later. Appraisal scores were multiplied by 5 to make them compatible with previously recorded type traits that

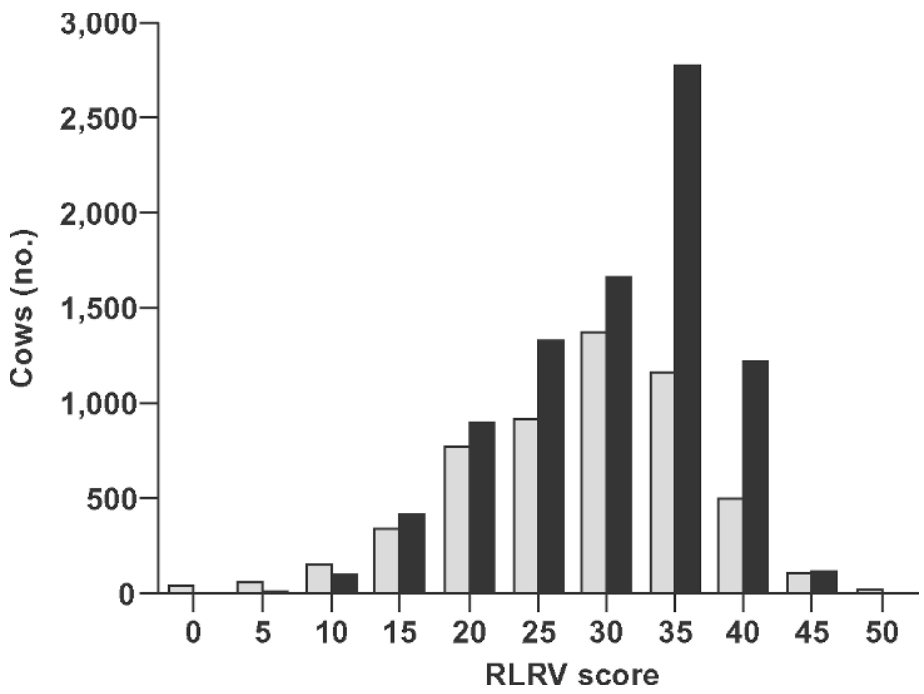

Figure 1. Frequency of rear legs (rear view; RLRV) scores for Brown Swiss (black bars) and Guernseys (gray bars). Original Brown Swiss scores of 1 through 9 were multiplied by 5; Guernsey frequencies were grouped as $0=1$ to $2,5=3$ to $7,10=8$ to $12, \ldots 45=43$ to $47,50=48$ to 50 .

were scored from 1 to 50 . The 865 sires averaged 8.9 daughters with appraisals. Scores were required for each of the 15 other linear type traits.

Guernsey data were 5,437 records from October 2004 through March 2006 ( 1 herd appraisal from October 2002 also was included) for 4,749 cows in 229 herds. Scores were assigned by 19 appraisers; 3 appraisers contributed $61 \%$ of the appraisals. Pedigree data (17,827 records) included ancestors born during 1985 and later. The 603 sires averaged 7.9 daughters with appraisals. For both breeds, 9 unknown-parent groups were defined, each with 2 birth years included.

Figure 1 shows the frequency of RLRV scores for both breeds. Brown Swiss cattle tended to have higher scores, higher median scores, and greater skew from a normal distribution than did Guernseys. The difference reflects differences in breed programs as well as biological differences. Because the majority of Brown Swiss cows have fairly straight legs, they intentionally are scored as 7 (rather than 5) so that higher scores (8 and 9) will be assigned to cows that toe in (R. R. Neitzel, unpublished data).

\section{Estimation of Variance Components}

Variance components were estimated with MTC (multitrait REML estimation of variance components program by canonical transformation with support for multiple random effects; I. Misztal, University of Georgia, Athens, personal communication); calculations were as described by Gengler et al. (1997a, 1997b, 1999) 
using expectation-maximization REML and canonical transformation as described in Misztal (1994) and Wiggans et al. (2004). The model included fixed effects for the interaction of herd, appraisal date, and parity (first or later); appraisal age (2-mo group; more months included for youngest and oldest ages) within parity (29 levels for each breed); and lactation stage (1 through 8 as assigned by the breed association) within parity (1, 2 , and $\geq 3$ ) and random effects for animal, permanent environment, and residual. The expectation-maximization REML algorithms used previously (e.g., Misztal et al., 1995) were modified because they gave unstable estimates and poor convergence in other work with small data sets (N. Gengler, unpublished data). Estimates of variance components also tended to move quickly beyond acceptable limits. The modification was a deceleration, which was implemented by halving the updating steps of variance components.

\section{Calculation of Evaluations}

The evaluations for linear type traits used a multitrait model. As done routinely for Brown Swiss and Guernsey type evaluations (Gengler et al., 1999), an effect for the interaction of herd and sire (945 levels for Brown Swiss; 586 levels for Guernseys) was included in the model (in addition to the effects included for variance-component estimation) to restrict the impact of bulls with evaluations based on daughters in only 1 herd, and $40 \%$ of the permanent environmental variance was assigned. Missing values were allowed for linear traits other than RLRV. Data edits for routine national type evaluations were imposed (Animal Improvement Programs Laboratory, 2005). For Brown Swiss, scores at ages beyond $68 \mathrm{mo}$ and records for cows that were not scored during their first 2 lactations were excluded, which resulted in 6,407 records for the calculation of evaluations; all Guernsey data were included because Guernseys do not require appraisal in early parities.

A canonical transformation was applied to minimize computational demands. Because some traits had missing values, the technique of Ducrocq and Besbes (1993) was used to estimate missing values at each iteration so that the solutions for all effects would not be affected by the missing values. Initial efforts with this approach to integrate RLRV data with historical data starting with appraisals in 1980 did not converge satisfactorily, probably because RLRV observations had to be estimated for the first $23 \mathrm{yr}$ of data. As a result, type evaluations were calculated in 2 steps. First, the current evaluation system for linear type traits was used unchanged for all traits except RLRV. Second, RLRV was included in a multitrait evaluation using only the observations with RLRV. This approach gave the RLRV evaluation the benefit of information from correlated traits but did not require the estimation of many missing values. No adjustment for heterogeneous variance was done for the second set of evaluations to minimize the computations required and because the stability of such an adjustment cannot be guaranteed for limited time periods. The overall approach was a compromise between optimal use of correlated information and feasibility.

\section{RESULTS AND DISCUSSION}

\section{Variance Components}

Estimates of variance components converged and were stable with the deceleration algorithm. The number of iteration rounds to convergence tended to be much larger $(>400)$ than for previous computations $(<200)$ of similar variance components (G. R. Wiggans, unpublished data). The delay in convergence was not merely a consequence of deceleration, because the evaluation system could not converge without deceleration. The application of the deceleration algorithm did not overly extend the computing time that was required for estimation of variance components because the data sets were small.

Estimated standard deviations (SD) and heritabilities for the 15 linear traits that are currently evaluated and RLRV are in Table 1. Guernsey SD were slightly larger than Brown Swiss SD; differences could be the result of different breed scoring systems. The largest SD was for fore udder attachment (7.6, Brown Swiss; 8.7, Guernseys). The smallest SD were for thurl width of Brown Swiss (5.5) and body depth of Guernseys (6.6).

Heritabilities for the records that included RLRV data (Table 1) ranged from 0.099 for rear legs (side view) to 0.453 for stature for Brown Swiss and from 0.078 for RLRV to 0.428 for stature for Guernseys. Heritability for RLRV was 0.102 for Brown Swiss. FuerstWaltl et al. (1998), DeGroot et al. (2002), and Reinhardt et al. (2005) reported RLRV heritabilities of $<0.12$ for Holsteins. McDaniel (1997) suggested that low heritability estimates for RLRV may result from variations in trait measurement rather than from the lack of genetic variation and that larger underlying differences may be masked by discrepancies in scoring. Other traits with low heritability estimates $(<0.12)$ from records with RLRV data (Table 1) were rear legs (side view) for Brown Swiss and foot angle for Brown Swiss and Guernseys. Heritabilities used for the current evaluations (Wiggans et al., 2004) are 0.18 for rear legs (side view) for Brown Swiss and 0.13 and 0.10 for Brown Swiss and Guernsey foot angle, respectively.

Differences between current heritabilities (Wiggans et al., 2004) and those from records with RLRV data 
Table 1. Estimated total SD (square root of sum of residual, genetic, and permanent environmental variances), heritabilities, and differences between heritabilities for 16 linear type traits by breed

\begin{tabular}{|c|c|c|c|c|c|c|c|c|}
\hline \multirow[b]{3}{*}{ Trait } & \multicolumn{4}{|c|}{ Brown Swiss } & \multicolumn{4}{|c|}{ Guernsey } \\
\hline & \multirow[b]{2}{*}{ Total SD } & \multicolumn{3}{|c|}{ Heritability } & \multirow[b]{2}{*}{ Total SD } & \multicolumn{3}{|c|}{ Heritability } \\
\hline & & $\begin{array}{l}\text { Records } \\
\text { with data } \\
\text { for rear legs } \\
\text { (rear view) }\end{array}$ & Current $^{1}$ & Difference $^{2}$ & & $\begin{array}{l}\text { Records } \\
\text { with data } \\
\text { for rear legs } \\
\text { (rear view) }\end{array}$ & Current & Difference \\
\hline Stature & 6.7 & 0.453 & 0.432 & 0.021 & 8.6 & 0.428 & 0.488 & -0.060 \\
\hline Foot angle & 6.6 & 0.119 & 0.130 & 0.011 & 6.6 & 0.085 & 0.096 & -0.011 \\
\hline Rear legs (side view) & 6.1 & 0.099 & 0.181 & -0.082 & 6.8 & 0.151 & 0.157 & -0.006 \\
\hline Body depth & 6.5 & 0.201 & 0.249 & -0.048 & 6.6 & 0.247 & 0.320 & -0.073 \\
\hline Rump angle & 6.4 & 0.212 & 0.274 & -0.062 & 7.2 & 0.303 & 0.413 & -0.110 \\
\hline Thurl width & 5.5 & 0.151 & 0.176 & -0.025 & 7.0 & 0.248 & 0.286 & -0.038 \\
\hline Fore udder attachment & 7.6 & 0.210 & 0.221 & -0.011 & 8.7 & 0.333 & 0.288 & 0.045 \\
\hline Rear udder height & 6.5 & 0.230 & 0.215 & 0.015 & 7.3 & 0.288 & 0.281 & 0.007 \\
\hline Rear legs (rear view) & 5.8 & 0.102 & - & - & 7.4 & 0.078 & - & - \\
\hline
\end{tabular}

${ }^{1}$ Wiggans et al. (2004).

${ }^{2}$ Difference $=$ heritability estimated from records with data for rear legs (rear view) - current heritability.

also are presented in Table 1. Heritabilities averaged 0.030 lower for Brown Swiss and 0.021 lower for Guernseys for the 15 currently evaluated traits and ranged from 0.110 lower for Guernsey rump angle to 0.045 higher for Guernsey fore udder attachment. The change in heritabilities may reflect sampling errors from the limited amount of data, especially for dams because of the short period of data collection, or changes in parameters over time.

Phenotypic and genetic correlations of the 15 currently evaluated linear type traits with RLRV are shown in Table 2. For Brown Swiss, rear udder width had the highest genetic correlation (0.71) with RLRV; rump angle had the most negative correlation $(-0.19)$. For Guernseys, the highest genetic correlations with RLRV were 0.43 for rear udder width and 0.42 for body depth, and the most negative correlation was -0.46 for rear legs (side view). The relatively high genetic correlation of RLRV with rear udder width and moderate correlations with rear udder height (0.31, Brown Swiss; 0.22, Guernseys) may suggest a link between udder fullness and RLRV. Short et al. (1991) reported a genetic correlation with RLRV of 0.35 for rear udder width and 0.29 for rear udder height for Holsteins and noted that the

Table 2. Estimated phenotypic and genetic correlations of 15 linear type traits with rear legs (rear view) by breed

\begin{tabular}{|c|c|c|c|c|}
\hline \multirow[b]{2}{*}{ Trait } & \multicolumn{2}{|c|}{ Brown Swiss } & \multicolumn{2}{|c|}{ Guernsey } \\
\hline & Phenotypic & Genetic & Phenotypic & Genetic \\
\hline Stature & 0.07 & 0.15 & 0.04 & 0.18 \\
\hline Strength & 0.09 & 0.49 & 0.12 & 0.30 \\
\hline Dairy form & 0.07 & 0.44 & 0.08 & 0.34 \\
\hline Foot angle & 0.19 & 0.19 & 0.21 & 0.31 \\
\hline Rear legs (side view) & -0.16 & -0.11 & -0.19 & -0.46 \\
\hline Body depth & 0.11 & 0.40 & 0.08 & 0.42 \\
\hline Rump angle & -0.03 & -0.19 & -0.06 & -0.08 \\
\hline Thurl width & 0.09 & 0.47 & 0.06 & 0.16 \\
\hline Fore udder attachment & 0.10 & 0.24 & 0.06 & 0.06 \\
\hline Rear udder height & 0.14 & 0.31 & 0.11 & 0.22 \\
\hline Rear udder width & 0.20 & 0.71 & 0.23 & 0.43 \\
\hline Udder depth & 0.03 & 0.01 & -0.01 & -0.11 \\
\hline Udder cleft & 0.05 & 0.09 & 0.03 & -0.04 \\
\hline Front teat placement & 0.05 & 0.19 & 0.03 & 0.19 \\
\hline Teat length & 0.02 & 0.04 & 0.02 & 0.13 \\
\hline
\end{tabular}


Table 3. Descriptive statistics for evaluations ${ }^{1}$ for rear legs (rear view) for cows and for bulls with $\geq 5$ daughters

\begin{tabular}{lllllc}
\hline & \multicolumn{2}{c}{ Cows } & & \multicolumn{2}{c}{$\begin{array}{c}\text { Bulls with } \\
\geq 5 \text { daughters }\end{array}$} \\
\cline { 2 - 3 } \cline { 5 - 6 } Statistic & $\begin{array}{l}\text { Brown } \\
\text { Swiss }\end{array}$ & Guernsey & & $\begin{array}{l}\text { Brown } \\
\text { Swiss }\end{array}$ & Guernsey \\
\hline Animals, no. & 5,709 & 4,749 & & 228 & 213 \\
Daughters, no. & - & - & & 20.9 & 19.0 \\
Herds, no. & - & - & & 12.8 & 10.4 \\
PTA & & & & 0.02 & 0.07 \\
Mean & 0.01 & 0.08 & & -1.20 & -1.70 \\
Minimum & -1.50 & -2.70 & & 1.30 & 2.20 \\
Maximum & 1.30 & 2.60 & & 0.43 & 0.61 \\
SD & 0.39 & 0.52 & & 49.6 & 44.7 \\
Reliability, \% & 32.9 & 29.9 & & \\
\hline
\end{tabular}

${ }^{1}$ Evaluations are PTA based on a 50 -point scale.

volume of milk in the udder affects RLRV. The fullness of the udder may cause the rear legs to be set out more and reduce how much the legs are hocked in and toed out. A uniform time for scoring (e.g., just prior to or after milking) could be implemented to alleviate bias caused by fullness of the udder. However, cows that would have had lower RLRV scores if their udders had been less full likely would still have mobility problems and would score poorly for RLRV after dry off. The model effect for lactation stage also should help to eliminate bias due to udder fullness.

\section{Evaluations}

Evaluation statistics are shown in Table 3 for PTA based on a 50-point scale. Although heritability for Guernseys was lower than for Brown Swiss, SD of evaluations were greater, which reflects the larger variance of RLRV for Guernseys; phenotypic SD of RLRV (Table 1) also was larger for Guernseys than for Brown Swiss. The greater variability in Guernsey RLRV scores may have resulted from the different scales used in scoring. Mean PTA were close to 0 because the birth years of cows with data are close to the base year of 2000 and little genetic trend appears to have occurred.

\section{CONCLUSIONS}

Inclusion of RLRV in appraisal programs allows breeders to obtain a better description of the components of locomotion. The cows that tend to score higher for RLRV (i.e., straighter legs from the rear) also tend to have a steeper foot angle and straighter rear legs when viewed from the side. A cow with straighter rear legs is expected to walk with greater forward and less sideways motion, which would reduce udder contact and damage (and associated SCS) as well as joint impact and injury, and to be able to stand securely on any surface, which may result in better heat detection and higher fertility.

Genetic evaluations for Brown Swiss and Guernsey RLRV were released by USDA in May 2006. Because of the importance of locomotion traits, those evaluations should be useful in selection programs. Although RLRV had a relatively low heritability compared with other evaluated linear type traits, it is likely to be included in the feet-and-legs composite that is used for calculation of USDA-DHIA economic indexes for lifetime merit.

\section{ACKNOWLEDGMENTS}

N. Gengler, Research Associate of the National Fund for Scientific Research (Brussels, Belgium) acknowledges the financial support of his organization. The authors also thank S. Johnson (AGA, Reynoldsburg, $\mathrm{OH}$ ), T. J. Lawlor (Holstein Association USA, Brattleboro, VT), and S. M. Hubbard (Animal Improvement Programs Laboratory, Beltsville, MD) for review comments.

\section{REFERENCES}

Animal Improvement Programs Laboratory. 2005. USDA type evaluation description (Ayrshire, Brown Swiss, Guernsey, Jersey) 2005. http://aipl.arsusda.gov/reference/type/type.htm Accessed July 3, 2006.

Boettcher, P. J., J. C. M. Dekkers, L. D. Warnick, and S. J. Wells. 1998. Genetic analysis of clinical lameness in dairy cattle. J. Dairy Sci. 81:1148-1156.

Caraviello, D. Z., K. A. Weigel, and D. Gianola. 2004. Analysis of the relationship between type traits and functional survival in US Holstein cattle using a Weibull proportional hazards model. J. Dairy Sci. 87:2677-2686.

DeGroot, B. J., J. F. Keown, L. D. Van Vleck, and E. L. Marotz. 2002. Genetic parameters and responses of linear type, yield traits, and somatic cell scores to divergent selection for predicted transmitting ability for type in Holsteins. J. Dairy Sci. 85:1578-1585.

Ducrocq, V., and B. Besbes. 1993. Solution of multiple trait models with missing data on some traits. J. Anim. Breed. Genet. 110:81-92.

Fatehi, J., A. Stella, J. J. Shannon, and P. J. Boettcher. 2003. Genetic parameters for feet and leg traits evaluated in different environments. J. Dairy Sci. 86:861-866.

Fuerst-Waltl, B., J. Sölkner, A. Essl, I. Hoeschele, and C. Fuerst. 1998. Non-linearity in the genetic relationship between milk yield and type traits in Holstein cattle. Livest. Prod. Sci. 57:41-47.

Gengler, N., G. R. Wiggans, and J. R. Wright. 1999. Animal model genetic evaluation of type traits for five dairy cattle breeds. J. Dairy Sci. 82:1350. Online. Available http://jds.fass.org/

Gengler, N., G. R. Wiggans, J. R. Wright, H. D. Norman, and C. W. Wolfe. 1997a. Application of canonical transformation with missing values to multitrait evaluation of Jersey type. J. Dairy Sci. 80:2563-2571.

Gengler, N., G. R. Wiggans, J. R. Wright, H. D. Norman, and C. W. Wolfe. 1997b. Estimation of (co)variance components for Jersey type traits using a repeatability model. J. Dairy Sci. 80:18011806.

Holstein Association USA. 1996. Holstein Type-Production Sire Summaries, January 1996. Holstein Assoc. USA, Inc., Brattleboro, VT.

International Bull Evaluation Service. 2006a. Description of National Genetic Evaluation Systems for dairy cattle traits as applied in different Interbull member countries. http:/www-interbull. slu.se/national_ges_info2/begin-ges.html Accessed June 21, 2006. 
International Bull Evaluation Service. 2006b. Interbull routine genetic evaluation for conformation traits, May 2006. http://wwwinterbull.slu.se/conform/c-may06.html. Accessed June 21, 2006.

McDaniel, B. T. 1997. Breeding programs to reduce foot and leg problems. Interbull Bull. 15:115-122.

Misztal, I. 1994. Comparison of software packages in animal breeding. Proc. 5th World Congr. Genetics. Appl. Livest. Prod. Sci. 22:3-10.

Misztal, I., K. Weigel, and T. J. Lawlor. 1995. Approximation of estimates of (co)variance components with multiple-trait restricted maximum likelihood by multiple diagonalization for more than one random effect. J. Dairy Sci. 78:1862-1872.

National Animal Health Monitoring System. 2002. Dairy 2002. Part I: Reference of Dairy Health and Management in the United States. USDA, Animal and Plant Health Inspection Service, Veterinary Services, Center for Epidemiology and Animal Health, Fort Collins, CO.

Neitzel, R. 2003. Record news from the superintendent: Classification program updates. Brown Swiss Bull. 82(11):24.

Neitzel, R. 2004. Record news from the superintendent. Brown Swiss Bull. 83(12):28

Norman, H. D., R. L. Powell, J. R. Wright, and R. E. Pearson. 1996. Phenotypic relationship of yield and type scores from first lactation with herd life and profitability. J. Dairy Sci. 79:689-701.
Pérez-Cabal, M. A., and R. Alenda. 2002. Genetic relationships between lifetime profit and type traits in Spanish Holstein cows. J. Dairy Sci. 85:3480-3491.

Reinhardt, F., W. Ruten, and S. Rensing. 2005. Genetic evaluation for feet traits collected from young German Holstein bulls. Interbull Bull. 33:167-170.

Rogers, G. W. 1996. Using type for improving health of the udder and feet and legs. Interbull Bull. 12:33-41.

Sewalem, A., G. J. Kistemaker, F. Miglior, and B. J. Van Doormaal. 2004. Analysis of the relationship between type traits and functional survival in Canadian Holsteins using a Weibull proportional hazards model. J. Dairy Sci. 87:3938-3946.

Shapiro, L. S., and L. V. Swanson. 1991. Relationships among rump and rear leg type traits and reproductive performance in Holsteins. J. Dairy Sci. 74:2767-2773.

Short, T. H., T. J. Lawlor, Jr., and K. L. Lee. 1991. Genetic parameters for three experimental linear type traits. J. Dairy Sci. 74:2020-2025.

Tsuruta, S., I. Misztal, and T. J. Lawlor. 2005. Changing definition of productive life in US Holsteins: Effect on genetic correlations. J. Dairy Sci. 88:1156-1165.

Wiggans, G. R., N. Gengler, and J. R. Wright. 2004. Type trait (co)variance components for five dairy breeds. J. Dairy Sci. 87:2324-2330. 